\title{
POTENSI BAKTERI KITINOLITIK NR09 PADA BEBERAPA MEDIA PEMBAWA DALAM MENGHAMBAT PERTUMBUHAN JAMUR PATOGEN Sclerotium rolfsii dan Fusarium oxysporum PADA BENIH CABAI MERAH (Capsicum annuUm L.)
}

\section{THE POTENCY OF CHITINOLYTIC BACTERIAL NRO9 ON SOME CARRIER MEDIA IN HIBITING Sclerotium rolfsii and Fusarium oxysporum ON RED CHILLI SEEDLINGS (Capsicum annuUm L.)}

\author{
Deswidya Sukrisna Hutauruk* \\ Departemen Analisis Kesehatan, Fakultas Kesehatan, Universitas Efarina, Pematang Siantar \\ *Corresponding author: E-mail: sukrisna.hutauruk@gmail.com
}

\begin{abstract}
Abstrak
Penelitian ini bertujuan untuk mengetahui viabilitas isolat bakteri kitinolitik dalam beberapa media pembawa dan mengetahui potensi isolat bakteri kitinolitik pada berbagai media pembawa dalam mengendalikan penyakit rebah kecambah yang disebabkan oleh $F$. oxysporum dan $S$. rolfsii pada tanaman cabai merah. Metode yang digunakan dengan mengukur viabilitas dan kemampuan bakteri dalam media tumbuh dan media pembawa pada media MGMK setelah penyimpanan media pembawa selama 90 hari. Bakteri NR09 memiliki viabilitas yang baik pada media pembawa gambut dan janjang kelapa sawit dan memiliki potensi dalam menghambat serangan jamur patogen $S$. rolfsii dan $F$. oxysporum.
\end{abstract}

Kata kunci: NR09, Fusarium oxysporum, Sclerotium rolfsii , Gambut, Kompos Janjang Sawit

\begin{abstract}
This study was aims to determine the viability of chitinolytic bacterial isolates in some carrier media and to know the potential of chitinolytic bacterial isolates in various carrier media in controlling the disease of sprout caused by $F$. oxysporum and $S$. rolfsii on red pepper plant. The method used by measuring the viability and ability of bacteria in growing media and carrier media on MGMK media after storage of carrier media for 90 days. Bacteria NR09 has good viability on peat carrier media and palm oil bunch compost and has the potential to inhibit attack of pathogenic fungi S. rolfsii and F. oxysporum.
\end{abstract}

Keywords: NR09, Fusarium oxysporum, Sclerotium rolfsii, Peat, Palm oil bunch Compost

How to Cite: Hutauruk, D.S., 2018, Potensi Bakteri Kitinolitik NR09 pada Beberapa Media Pembawa dalam Menghambat Pertumbuhan Jamur Patogen Sclerotium rolfsii dan Fusarium oxysporum pada Benih Cabai Merah (Capsicum annuum L.), BioLink, Vol. 4 (2): Hal. 140-153 


\section{PENDAHULUAN}

Cabai merah (Capsicum annum L.) merupakan salah satu jenis tanaman hortikultura penting yang dibudidayakan secara komersial, hal ini disebabkan selain cabai memiliki kandungan gizi yang cukup lengkap juga memiliki peluang pasar yang baik dan nilai ekonomi yang tinggi, budidayanya relatif mudah untuk dilaksanakan, cepat menghasilkan karena tanaman ini memiliki umur panen relatif pendek (genjah), dan juga selain tanaman cabai kaya akan vitamin, juga dipercaya mempunyai khasiat obat yang sangat bermanfaat bagi kesehatan (Nurfalach, 2010). Cabai merah digunakan sebagai bahan penyedap dan pelengkap menu masakan hampir setiap hari di Indonesia. Sehingga hal ini mempengaruhi kebutuhan cabai yang akan meningkat sejalan dengan meningkatnya jumlah penduduk dan berkembangnya industri pangan.

Namun terdapat beberapa permasalahan yang dihadapi para petani pada proses penanaman bibit cabai hingga pemanenan. Benih mempunyai hubungan yang sangat erat dengan perkembangan dan penyebaran suatu penyakit atau patogen, mengingat benih merupakan struktur perbanyakan tanaman. Pada umumnya penyakit yang sering menyerang tanaman cabai merah adalah serangan jamur patogenik terutama disebabkan oleh lahan yang selalu lembab sehingga memungkinkan jamur berkembang dengan baik. Berdasarkan beberapa penelitian dilaporkan terdapat beberapa jamur patogen yang ditemukan pada benih cabai merah seperti Rhizoctonia sp., Fusarium spp, Pythium spp, Phytophthora capsici, Sclerotium rolfsii dan
Colletotrichum capsici (Mardinus, 2006 dan Semangun, 2007).

Fusarium oxysporum merupakan salah satu patogen tular tanah penyebab penyakit layu fusarium pada tanaman cabai. Spesies jamur Fusarium oxysporum merugikan para petani karena serangan jamur menyebabkan tanaman mengalami layu patologis yang berakhir dengan kematian (Juanda, 2009). Pada umumnya pengendalian Fusarium oxysporum yang dilakukan oleh para petani hanya secara mekanis yaitu dengan cara mencabut dan membuang tanaman yang sakit. Namun hal ini dinilai tidak efektif karena $F$. oxysporum merupakan patogen tular tanah yang dapat bertahan dalam jangka waktu yang cukup lama didalam tanah. Jamur Fusarium oxysporum memiliki tingkat ketahanan pada kategori agak tahan samapai sangat tahan (Chamzurni, 2010).

Sclerotium rolfsii merupakan jamur patogen penyebab penyakit rebah kecambah. Jamur Sclerotium termasuk pada patogen kontaminan yang terbawa dipermukaan atau bersama-sama benih dan terbawa pada bagian-bagian tanaman yang lain terinfeksi, propagul dan partikel tanah yang tercampur dengan benih. Semua bagian benih dapat diinfeksi oleh satu patogen atau lebih. Jamur patogen ini dapat menyebabkan biji cabai membusuk di dalam tanah, atau semai-semai dapat mati sebelum muncul ke permukaan tanah, batang semai muda yang masih lunak terserang pada pangkalnya menjadi basah dan mengerut sehingga semai rebah dan mati (Semangun, 2007).

Untuk mengatasi berbagai permasalahan perlu dilakukan tindakan 
pencegahan dan pemberantasan dalam budidaya tanaman cabai merah agar etap dapat berproduksi tinggi. Salah satu upaya yang telah dilakukan melalui berbagai penelitian adalah dengan penginokulasian bakteri kitinolitik.

Bakteri kitinolitik merupakan salah satu pengendali hayati jamur patogen yang potensial. Bakteri kitinolitik adalah bakteri yang mampu menghasilkan enzim kitinase untuk asimilasi kitin yang dimanfaatkan sebagai sumber karbon dan nitrogen bagi bakteri itu sendiri (Wu et al., 2001). Bakteri kitinolitik dapat memecah dan mendegradasi kitin penyusun dinding sel fungi sehingga bakteri ini sangat potensial untuk menghambat pertumbuhan fungi patogen pada tanaman. Bakteri kitinolitik mampu menurunkan rebah kecambah cabai merah hingga 80\% (Netti, 2014).

Dalam hal ini penelitian ini bertujuan untuk menguji dan meneliti viabilitas sel bakteri kitinolitik NR09 pada beberapa media pembawa. Disamping itu juga diuji kemampuan bakteri yang sudah disimpan dalam media pembawa dalam menghambat pertumbuhan jamur patogen $S$. rolfsii dan $F$. oxysporum yang menyerang kecambah cabai. Uji antagonis isolat bakteri potensial terhadap beberapa jamur patogen secara in vitro menunjukkan bahwa isolat bakteri NR09 memiliki persentase penghambatan yang tertinggi terhadap Rigidoporus microsporus, Sclerotium rolfsii dan Fusarium oxysporum dengan persentasi penghambatan masingmasing $\quad 63,6 \%$. 64,6\% dan $75,6 \%$ (Batubara, 2013).
Bahan pembawa atau carrier merupakan bahan tempat membawa sel hidup atau mikroba tertentu yang diinokulasikan di dalamnya dengan tujuan agar tetap hidup selama jangka waktu tertentu. Bahan pembawa perlu disterilisasi untuk menghindari adanya pertumbuhan mikrob indigenus (Putri, 2011).

\section{METODE PENELITIAN}

\section{Persiapan Bakteri Kitinolitik, Jamur patogen dan Media Pembawa.}

Media pembawa yang digunakan adalah tanah gambut dan kompos janjang kelapa sawit. Media pembawa dibuat dalam 4 variasi yaitu tanah gambut saja, tanah gambut yang ditambahkan dengan 2\% koloidal kitin, kompos janjang sawit saja dan kompos janjang sawit yang ditambahkan dengan $2 \%$ koloidal kitin. Peningkatan pH gambut dilakukan dengan penambahan 10\% CaCO3 hingga diperoleh $\mathrm{pH}$ sekitar $7-7,4$. Semua variasi media pembawa lalu distrerilisasi dengan otoklaf untuk mencegah kontaminasi terjadi.

Bakteri kitinolitik yang digunakan adalah Bakteri NR09. Bakteri kitinolitik NR09 berasal dari hasil isolasi dari kulit udang (Batubara, 2013). Molase-sodium nitrat yang dimasukkan kedalam media garam minimum merupakan media yang digunakan untuk perbanyakan sel bakteri dan diinkubasi hingga kerapatan sel $\approx 108 \mathrm{sel} / \mathrm{ml}$. Bakteri kitinolitik kemudian di inokulasikan kedalam setiap media pembawa kemudian disimpan selama 90 hari di suhu ruang. Jamur patogen Sclerotium rolfsii dan Fusarium oxysporum merupakan koleksi Laboratorium Mikrobiologi, 
Departemen Biologi, Fakultas MIPA, USU, Medan.

\section{Perhitungan Jumlah Sel Bakteri Dalam Media Pembawa dan Media Pertumbuhan}

Media pembawa yang telah dicampurkan dengan kultur bakteri kitinolitik diambil sebanyak $1 \mathrm{~g}$ kemudian dibuat pengenceran seri. Jumlah sel yang hidup dihitung dengan menyebarkan $1 \mathrm{ml}$ hasil pengenceran ke dalam agar MGM dengan 2\% kolodial kitin sebagai sumber karbon (MGMK). Penghitungan ini dilakukan pada hari ke-0 hingga hari ke 90. Jumlah sel pada media pertumbuhan dihitung dengan cara yang sama dengan perhitungan jumlah sel pada media pembawa. Jumlah sel (cfu/g) ditampilkan dalam bentuk nilai logaritma.

\section{Penghambatan Serangan Jamur Patogen pada Benih Cabai}

Jamur F. oxysporum dan S. rolfsii di biakkan dalam media glucose yeast broth dan diinkubasi selama 7 hari pada suhu kamar. Kemudian dicampur dengan $4 \mathrm{~kg}$ media tumbuh campuran tanah dan kompos steril dengan nisbah (3:1). Bakteri dalam media pembawa lalu dicampur dengan media pertumbuhan dan 20 benih cabai ditanam kedalam tiap nampan pertumbuhan. Setiap perlakuan memiliki kombinasi yang berbeda (Tabel 1).

Tabel 1. Kontrol dan kombinasi perlakuan pada pertumbuhan benih cabai

\begin{tabular}{|c|c|}
\hline Perlakuan & Keterangan \\
\hline Kontrol (-) & Tanpa perlakuan \\
\hline Kontrol S & Perlakuan S. rolfsii saja \\
\hline Kontrol F & Perlakuan $F$. oxysporum saja \\
\hline GN & tanah gambut + bakteri NR09 \\
\hline GKN & tanah gambut $+2 \%$ koloidal kitin + Bakteri NR09 \\
\hline JN & kompos janjang kelapa sawit + Bakteri NR09 \\
\hline JKN & kompos janjang kelapa sawit $+2 \%$ koloidal kitin + Bakteri NR09 \\
\hline SGN & S. rolfsii + tanah gambut + Bakteri NR09 \\
\hline SGKN & S. rolfsii + tanah gambut $+2 \%$ koloidal kitin + Bakteri $N R 09$ \\
\hline SJN & S. rolfsii + kompos janjang kelapa sawit + Bakteri NR09 \\
\hline SJKN & $\begin{array}{l}\text { S. Rolfsii + kompos janjang kelapa sawit }+2 \% \text { koloidal kitin }+ \\
\text { Bakteri NR09 }\end{array}$ \\
\hline FGN & F. oxysporum + tanah gambut + Bakteri NR09 \\
\hline FGKN & F. oxysporum + tanah gambut $+2 \%$ koloidal kitin + Bakteri NR09 \\
\hline FJN & F. oxysporum + kompos janjang kelapa sawit + Bakteri NR09 \\
\hline FJKN & $\begin{array}{l}\text { F. oxysporum }+ \text { kompos janjang kelapa sawit }+2 \% \text { koloidal kitin }+ \\
\text { Bakteri NR09 }\end{array}$ \\
\hline
\end{tabular}

\section{Parameter Serangan Jamur Patogen}

Pengamatan serangan jamur patogen terhadap benih cabai dilihat melalui tanaman yang terserang jamur patogen, tinggi tanaman, jumlah daun, dan berat kering kecambah selama persemaian 30 hari. Persentase tanaman yang terserang jamur patogen diukur dengan cara menjumlahkan tanaman yang rebah, abnormal dan tidak tumbuh dibagi jumlah tanaman yang tumbuh normal pada kontrol (-) x 100\%. Tinggi 
tanaman diukur mulai dari ujung akar sampai ujung batang kecambah. Jumlah helai daun yang tumbuh dan mampu bertahan pada tiap kecambah selama persemaian 30 hari dihitung. Untuk mendapatkan berat kering kecambah maka kecambah basah di oven hingga beratnya konstan.

\section{HASIL DAN PEMBAHASAN}

\section{Viabilitas Bakteri NR09 Pada Berbagai Media Pembawa}

Uji kemampuan hidup mikroba didasarkan pada daya viabilitas dan jumlah koloni populasi bakteri dalam media pembawa. Penentuan daya viabilitas bakteri pada media pembawa dilakukan dengan menghitung jumlah sel yang hidup dalam media MGMK. Jumlah sel bakteri kitinolitik lebih tinggi pada penyimpanan hari ke 90 dibandingkan penyimpanan hari ke 0, 30 dan 60. Sel bakteri NR09 memiliki viabilitas dan kemampuan tumbuh yang hampir sama pada kedua media tumbuh termasuk pada media yang diberi tambahan koloidal kitin 2\%. Terlihat bahwa jumlah sel bakteri NR09 semakin meningkat seiring dengan lamanya penyimpanan isolat. Hal ini mengasumsikan bahwa media pembawa gambut dan janjang kelapa sawit tersebut bersifat baik bagi pertumbuhan bakteri kitinolitik NR09 (Gambar 1).

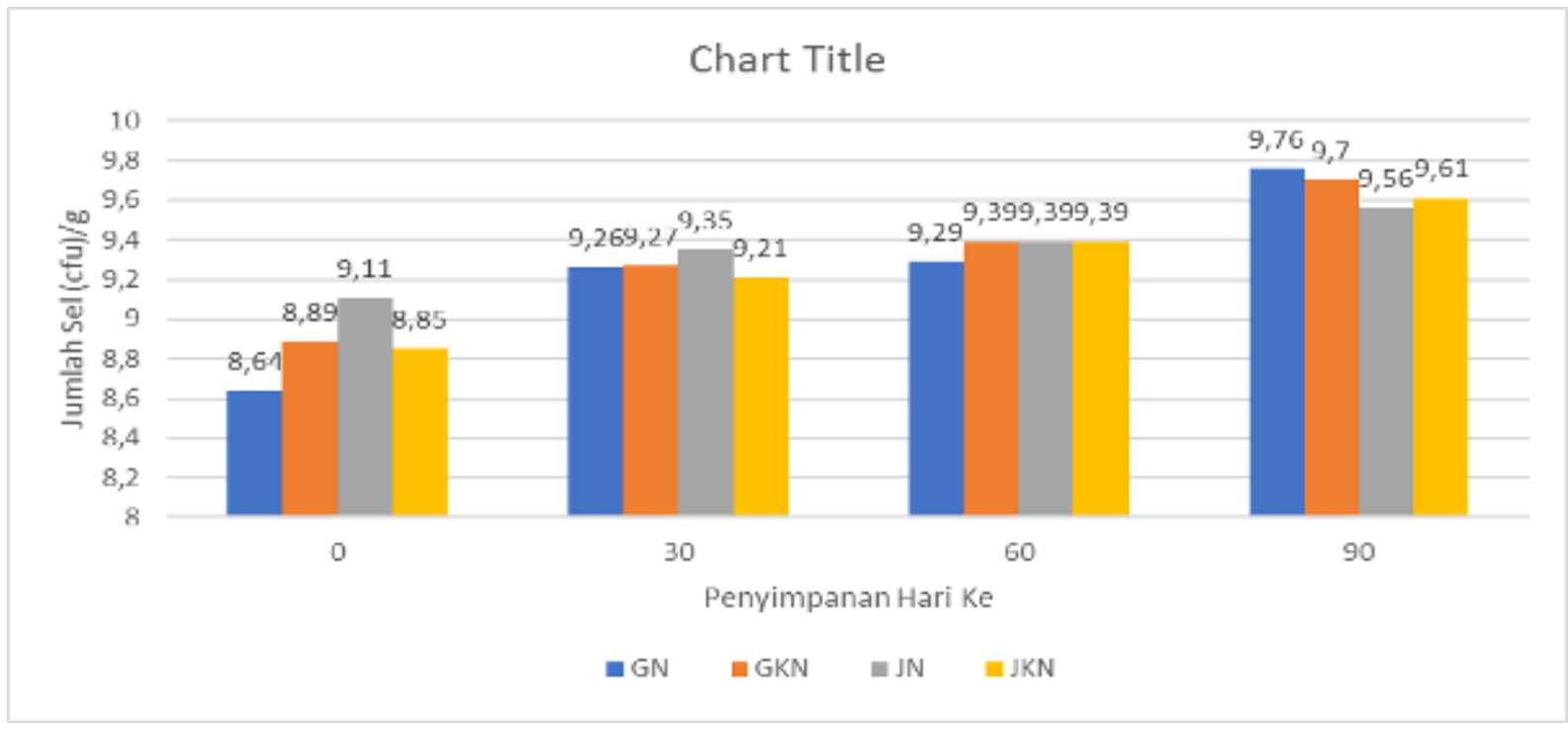

Gambar 1. Viabilitas Bakteri Kitinolitik NR09 pada media pembawa selama 90 hari

Viabilitas bakteri pada bahan pembawa didukung oleh bahan organik berupa partikel mudah larut seperti karbohidrat, protein, dan asam organik yang terdapat pada gambut (Jasinski, 2000) serta kadar air, kadar C-organik, dan kadar fosfor yang telah mendekati standar SNI pada media pembawa kompos janjang sawit. (Rahayu, 2010). Bahan organic sebagai bahan pembawa agen biokontrol mempunyai manfaat ganda karena selain menjadi bahan pemwa juga sebagai sumber nutrisi (food base) bagi agen biokontrol 
(Hoitink, 1999 dalam Sutari, et al. 2015). Sehingga bahan yg terdapat dalam kompos janjang sawit ini menjadi bahan energi bagi aktifitas metabolisme mikroorganisme. Selain itu viabilitas bakteri yang baik dan stabil ditentukan pula oleh kemampuan media pembawa mempertahankan kandungan air, $\mathrm{pH}$ yang netral serta kemampuan bakteri untuk memanfaatkan sumber karbon dan sumber energi yang ada pada media pembawa serta strategi bertahan bakteri dengan menggunakan mekanisme efisiensi yang dimiliki oleh bakteri itu sendiri (Jasinski, 2000).

\section{Viabilitas Bakteri NR09 Dalam Berbagai Media Tumbuh}

Viabilitas bakteri NR09 dalam media tumbuh dapat diketahui dengan menghitung jumlah koloni sel bakteri setelah masa persemaian bibit selama 30 hari dimana media tumbuh telah diinokulasikan dengan konidia $F$. oxysporum dan $S$. rolfsii. Jumlah sel bakteri NR09 pada media pembawa gambut menunjukkan bahwa pada setiap tahapnya jumlah sel mengalami peningkatan (Gambar 2.).

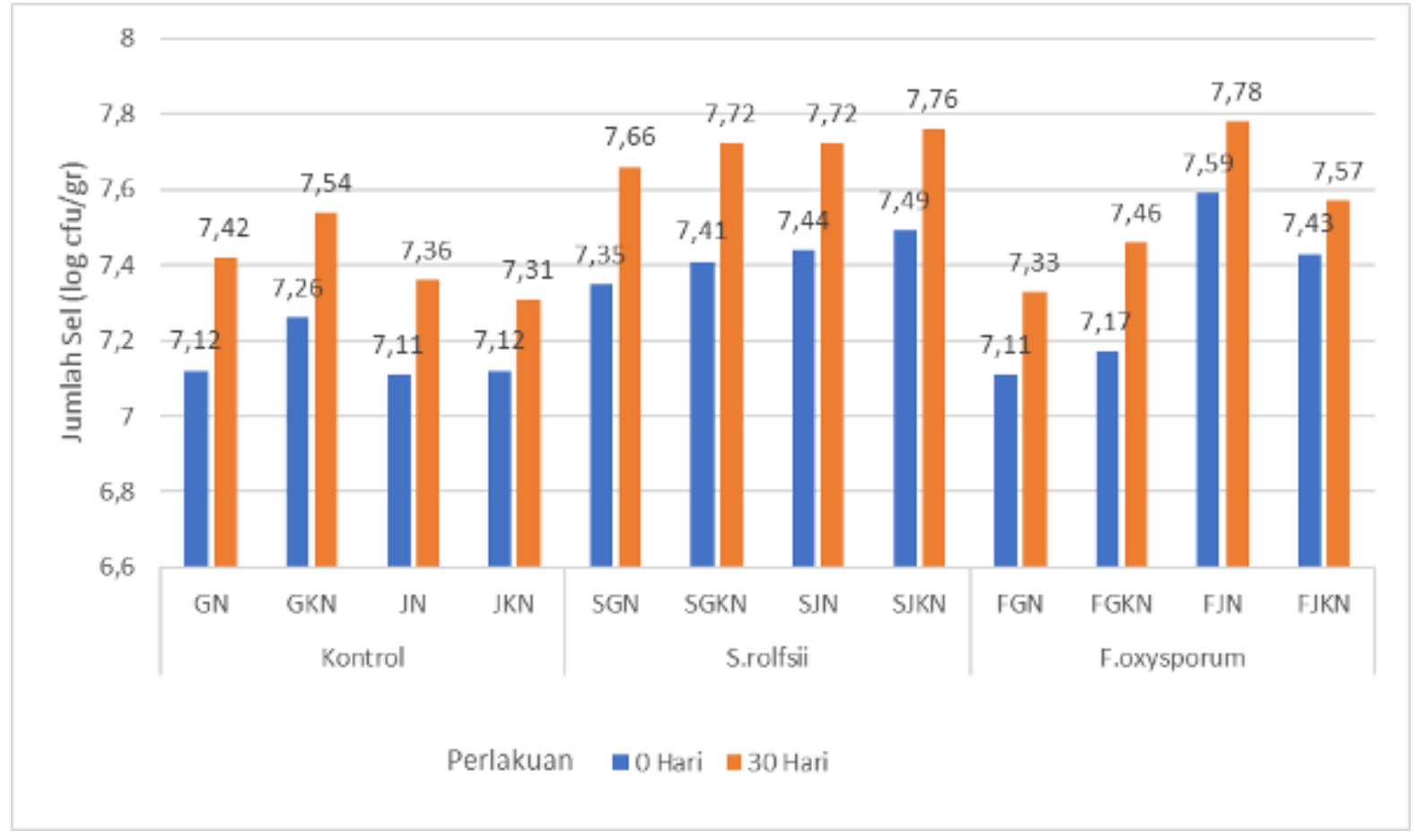

Gambar 2. Pertambahan jumlah sel bakteri NR09 dalam media pertumbuhan cabai selama masa semai 30 hari 
Pada hasil pengamatan terlihat bahwa tambahan koloidal kitin cukup berpengaruh terhadap peningkatan jumlah sel. Namun ada beberapa media pembawa tanpa tambahan koloidal lebih tinggi dibandingkan dengan tambahan koloidal kitin. Terdapat beberapa kemungkinan yang menyebabkan hal ini terjadi seperti sumber nutrisi didapatkan oleh bakteri kitinolitik melalui pendegradasian dinding sel fungi ataupun nutrisi dalam media pembawa masih dalam jumlah yang cukup untuk pertumbuhan bakteri tersebut.

Meningkatnya jumlah sel bakteri pada media tumbuh yang telah diinokulasi dengan bakteri patogen $F$. oxysporum dan $S$. rolfsii menunjukkan kemampuan bakteri kitinolitik NR09 dalam memecah dan mendegradasi kitin penyusun dinding sel fungi melalui enzim kitinase yang dihasilkannya dan dimanfaatkan sebagai sumber karbon dan nitrogen bagi bakteri itu sendiri. Hal ini menjadikan bakteri kitinolitik NR09 menjadi salah satu bakteri pengendali hayati yang potensial untuk menghambat pertumbuhan fungi patogen.

\section{Pertumbuhan bibit cabai}

Pertumbuhan bibit cabai selama persemaian 30 hari pada perlakuan pemberian bakteri dalam media pembawa baik yang tidak ditambah kitin maupun yang ditambah kitin menunjukkan pertumbuhan yang hamper sama dengan kontrol (-), perlakuan benih tanpa pemberian jamur dan bakteri. Dari hasil perlakuan dengan pemberian jamur patogen $F$. oxysporum dan $S$. rolfsii dan bakteri dalam media pembawa dengan penambahan koloidal kitin maupun tidak diberi penambahan kolidal terlihat jumlah benih yang tumbuh dalam kategori baik karena mampu tumbuh hingga diatas 50\% dibandingkan dengan pertumbuhan benih pada tanah yang hanya diinokulasikan dengan jamur $F$. oxysporum dan S. rolfsii saja (Gambar 3).

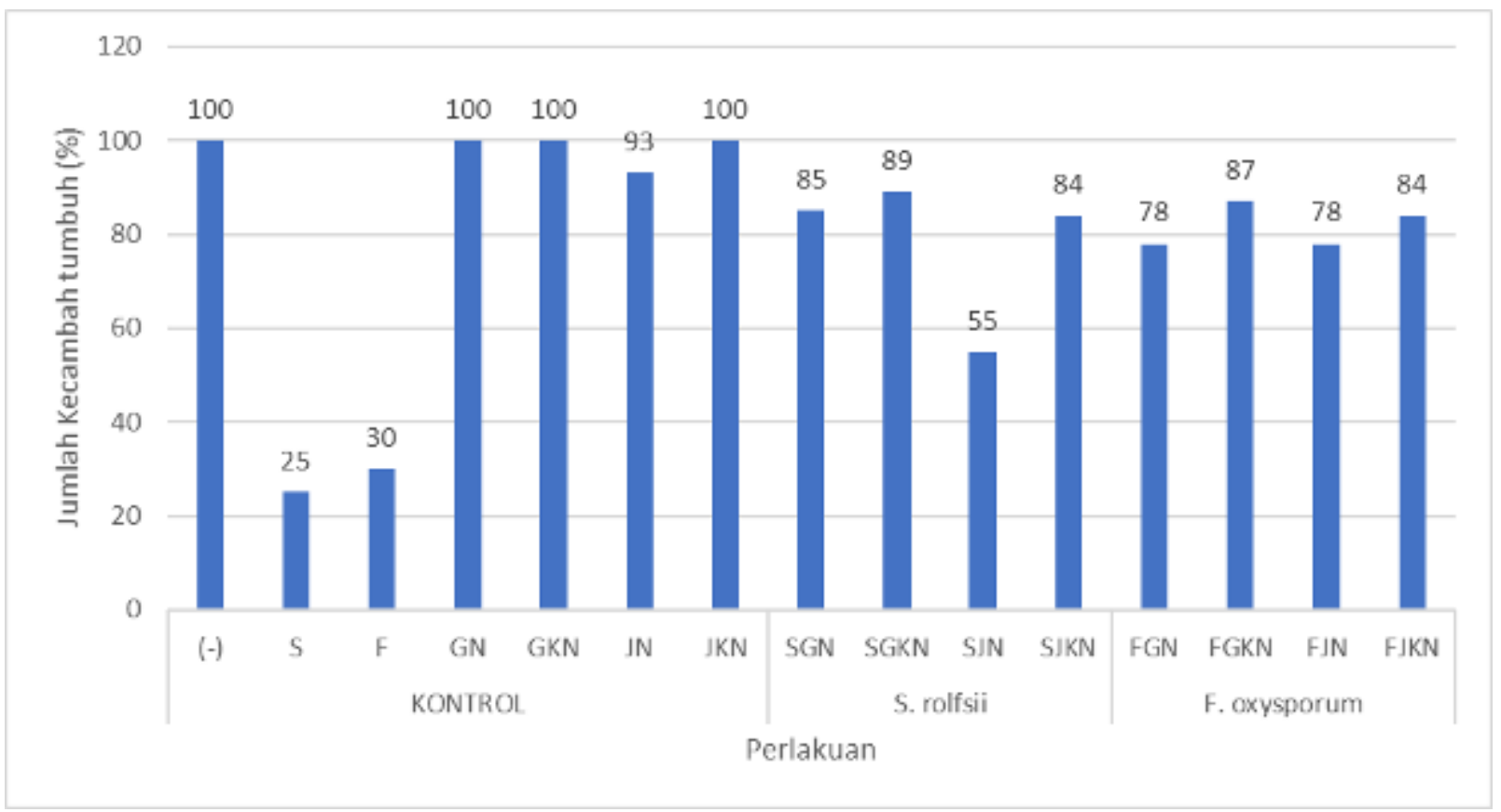


Gambar 3. Grafik pertumbuhan bibit cabai selama 30 hari masa semai pada berbagai jenis media pembawa.

Tingginya jumlah kecambah yang tumbuh pada media pertumbuhan tidak lepas dari kemampuan bakteri kitinolitik NR09 dalam menurunkan serangan $F$. oxysporum dan $S$. rolfsii dimana bakteri ini menghasilkan enzim kitinase (Suryanto et al., 2010; Batubara, 2013). Kitinase bersama dengan glukanase menunjukkan protein antifungi yang dapat melisis dinding sel jamur sehingga pertumbuhan jamur terhambat (Holetz et al., 2002) sehingga serangan jamur terhadap benih cabai juga menurun.

\section{Penghambatan Serangan Jamur}

Patogen $F$. oxysporum dan $S$. rolfsii

Penghambatan serangan jamur patogen oleh bakteri kitinolitik terlihat berbeda pada setiap perlakuan. Serangan jamur patogen terhadap kecambah cabai terlihat dari jumlah pertumbuhan kecambah dan betuk morfologi kecambah yang tidak normal. Pada penginokulasian jamur patogen pada media tumbuh tanpa bakteri kitinolitik menunjukkan 75\% kecambah telah diinfeksi. Namun pada perlakuan dengan penginokulasian bakteri kitinolitik dalam media tumbuh menunjukkan penurunan persentase kecambah yang terserang jamur patogen. Perbandingan penghambatan serangan jamur terlihat jelas (gambar 4).

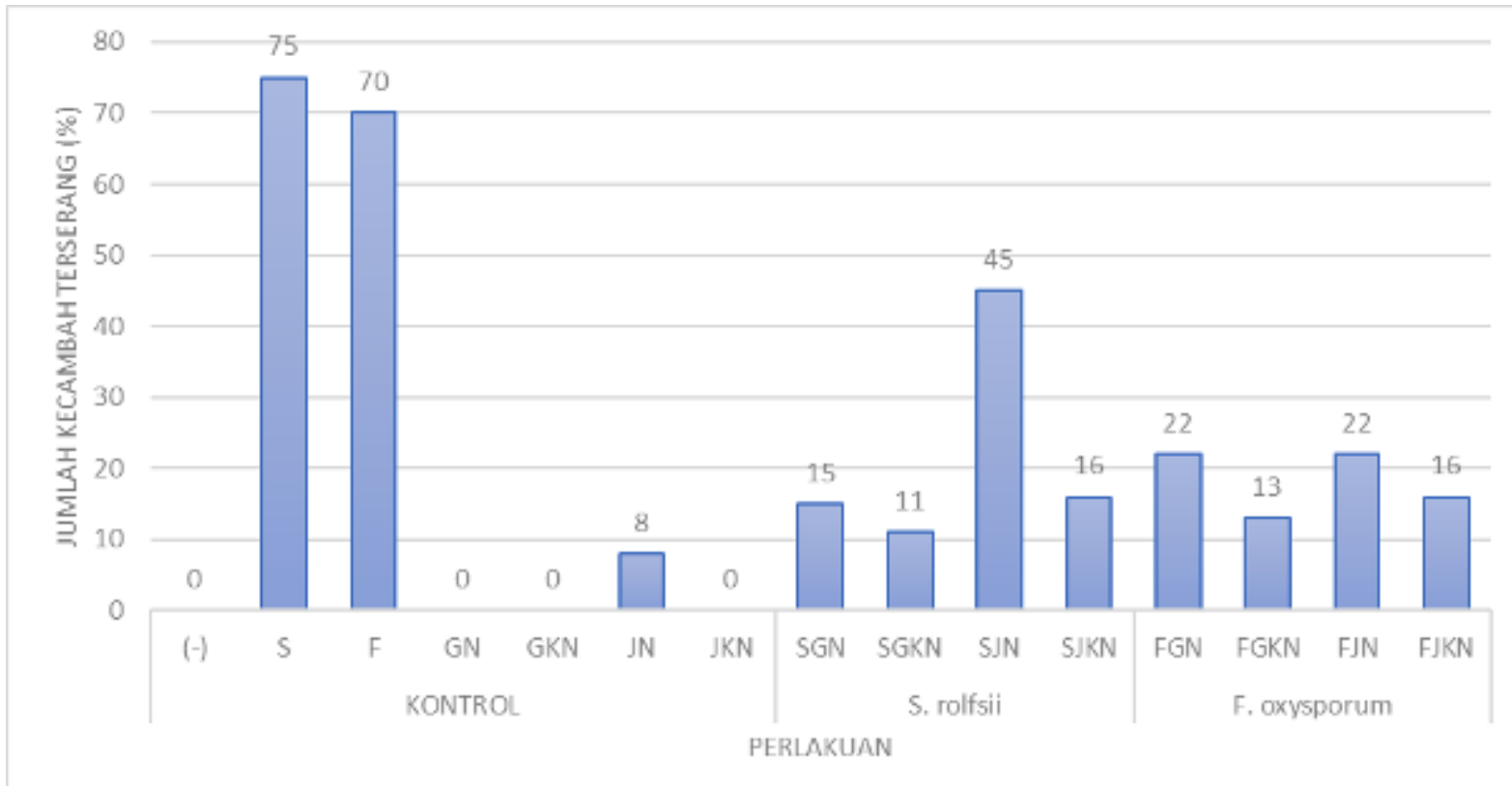

Gambar 4. Potensi penurunan serangan jamur patogen $S$. rolfsii dan F. oxysporum setelah penambahan isolat bakteri NR09 dalam media pembawa

Penghambatan serangan jamur patogen yang paling tinggi dilihat dari rendahnya serangan jamur pada benih. Rendahnya serangan jamur patogen pada benih menunjukkan kemampuan bakteri NR09 dalam menghambat dan mengendalikan pertumbuhanan $F$. oxysporum dan $S$. rolfsii pada benih cabai. Kemampuan bakteri NR09 dalam menghambat jamur patogen lebih tinggi pada penambahan koloidal kitin 2\% kedalam media pembawa. Protein 
antijamur dan metabolit seperti hidrolase glikosil lainnya, pengikatan kitin, protein dan antibiotik juga memungkinkan keterlibatan dalam menekan serangan jamur pada bibit cabai (Suryanto et al., 2010).

Pengamatan secara langsung menunjukkan perkecambahan benih yang terinfeksi jamur patogen menyebabkan pertumbuhan beberapa organ tumbuhan terganggu seperti morfologi batang dan tinggi tanaman, jumlah dan bentuk daun yang tumbuh hingga mempengaruhi berat kering tanaman.

\section{Pengaruh Jamur Patogen Terhadap Berat Kering, Tinggi dan Jumlah Daun Tanaman}

Dari gambar terlihat jamur patogen $S$. rolfsii dan $F$. oxysporum jelas mampu menginfeksi bibit baik diawal persemaian maupun setelah tanaman berkecambah dengan merusak embrio bibit cabai sehingga mempengaruhi berat kering tanaman tersebut.
Prabowo, (2008) menunjukkan bahwa serangan jamur menyebabkan daya berkecambah, panjang hipokotil, panjang akar, dan berat kering menjadi lebih rendah dibandingkan kontrol. Justice dan Bass (2002) menyatakan serangan jamur juga menyebabkan berat segar dan berat kering kecambah rendah. Hal ini karena jamur telah merusak bagian dalam benih (embrio dan cadangan makanan) sehingga berat basah dan kering menurun.

Perbandingan berat kering tanaman control dengan tanaman yang di inokulasikan dengan jamur patogen tidak jauh berbeda (Gambar 5). Bakteri kitinolitik NR09 mampu mempertahankan berat kering kecambah. Hal ini menunjukkan viabilitas dan kemampuan bakteri NR09 dalam menekan pertumbuhan jamur patogen dan mempertahankan pertumbuhan kecambah tanaman berkembang dengan baik.

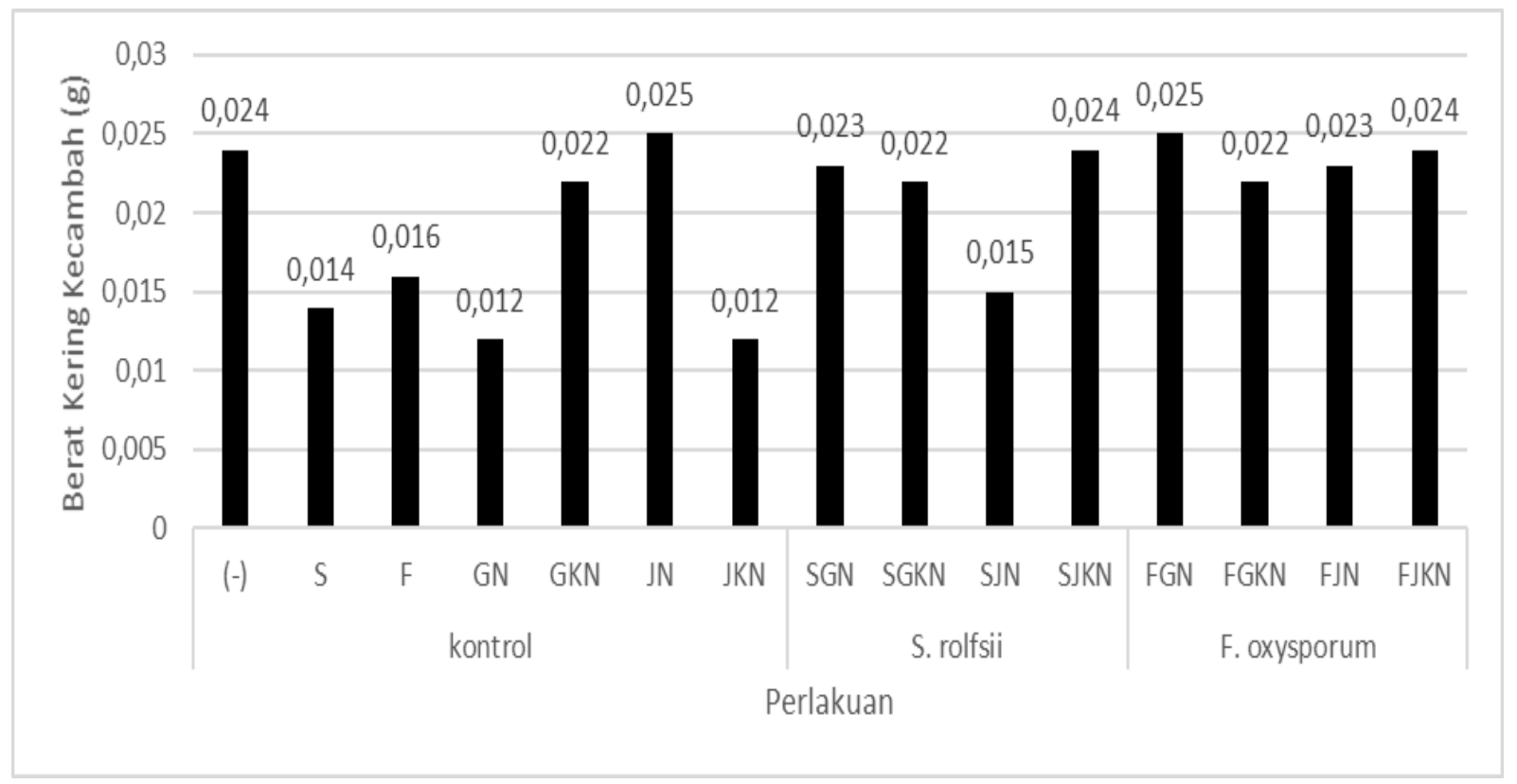


Gambar 5. Berat kering kecambah cabai setelah perlakuan isolat bakteri NR09 dalam media pembawa

Rusaknya struktur benih mulai dari persemaian mengganggu proses perkecambahan sehingga proses pertumbuhan organ-organ tubuh menjadi kurang optimal yang berakibat pada berat kering tanaman yang menurun.

Pengaruh jamur patogen juga terlihat dari tinggi kecambah selama proses pengamatan berlangsung. Alcivar et al., 2007 menyatakan tinggi dan hasil tanaman berkurang bisa terjadi karena penyakit, defisiensi unsur hara dan kompetisi dalam menyerap air yang tersedia. Mekanisme masuknya jamur patogen ke dalam jaringan tanaman yang mampu mempengaruhi tinggi tanaman dengan cara penetrasi dimana miselium menginfeksi bagian akar dan masuk hingga pembuluh xilem kemudian miselium fungi menghasilkan toksik dengan mensekresikan enzim selulotik dan asam oksalat yang menjadikan jaringan menjadi lunak sehingga tanaman cepat kehilangan air kemudian mati (Iskandar dan Wilesawati, 2005). Penyakit tular tanah yang disebabkan oleh cendawan $F$. oxysporum mempengaruhi tingkat ketahanan, pertumbuhan tanaman (tinggi tanaman) dan biomassa buah (Wandani et al., 2015).

Namun hal ini tidak terlalu berpengaruh pada tanaman yang diinokulasikan dengan bakteri NR09 dalam media pembawa. Rata-rata Tinggi tanaman terlihat lebih tinggi pada perlakuan dibandingkan kontrol. Hal ini menunjukkan bahwa isolat bakteri yang digunakan tidak mengganggu pertumbuhan dan tidak bersifat patogen terhadap benih cabai yang ditanaman selama pengamatan serta bakteri NR09 diindikasikan mampu menstimulasi mekanisme pertahanan dalam melindungi benih dari serangan jamur patogen dan menghasilkan zat pengatur tumbuh sehingga pertumbuhan kecambah bisa lebih baik (Gambar 6).

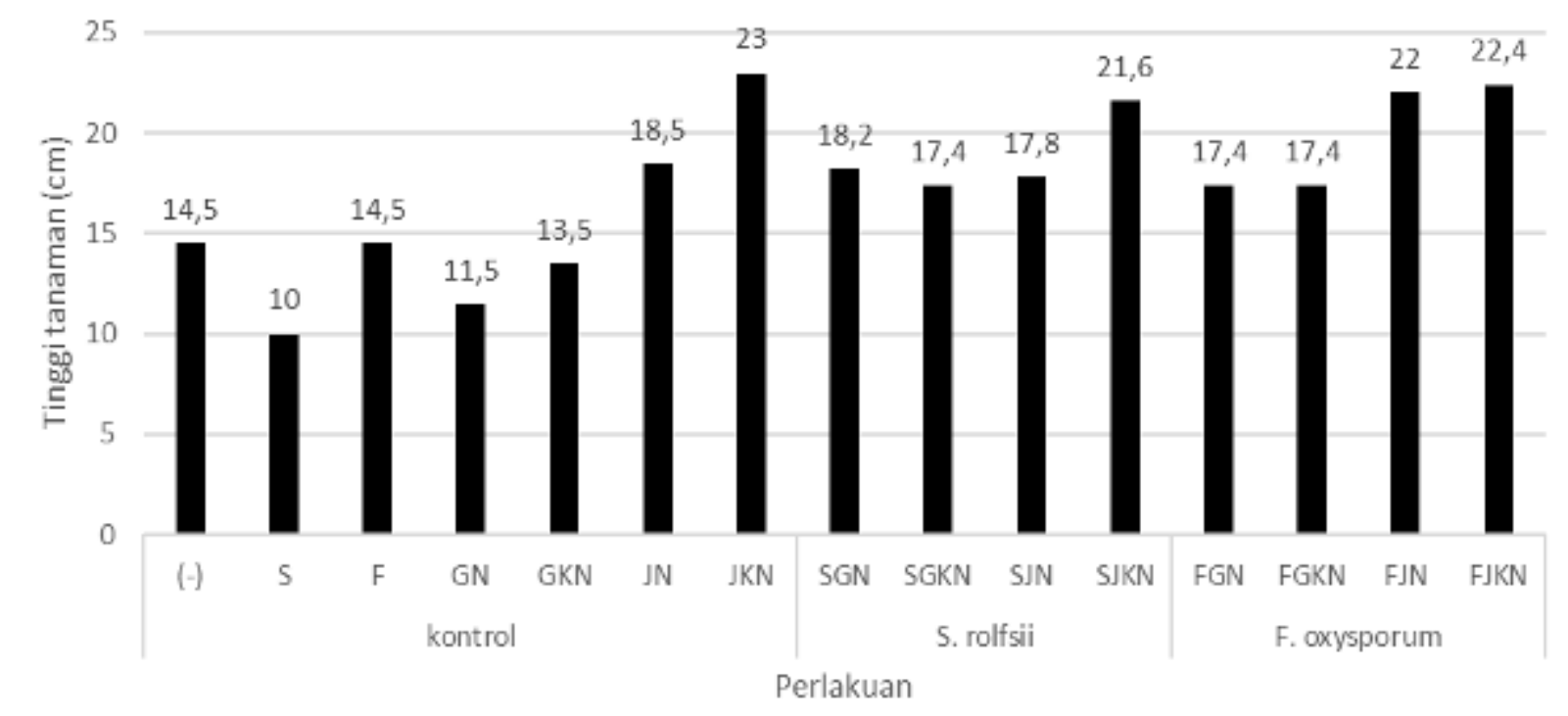


Gambar 6. Tinggi kecambah cabai setelah perlakuan isolat bakteri NR09 dalam media pembawa yang berbeda

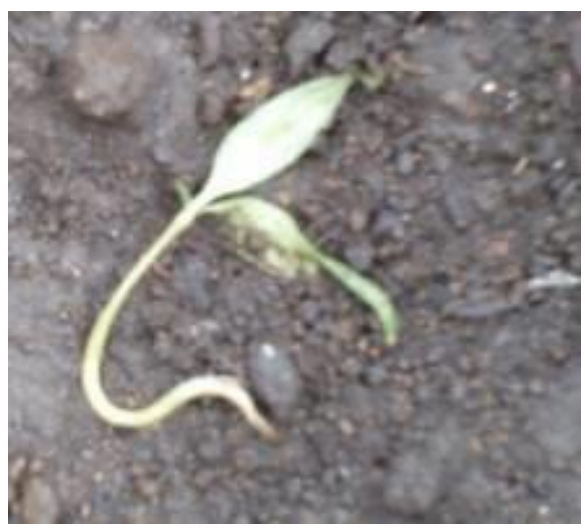

Gambar 7. Bentuk abnormal batang tanaman cabai akibat jamur pathogen

Infeksi yang diakibatkan jamur patogen mempengaruhi batang tanaman secara langsung mempengaruhi pertumbuhan jumlah dan bentuk morfologi daun. Daun yang terserang

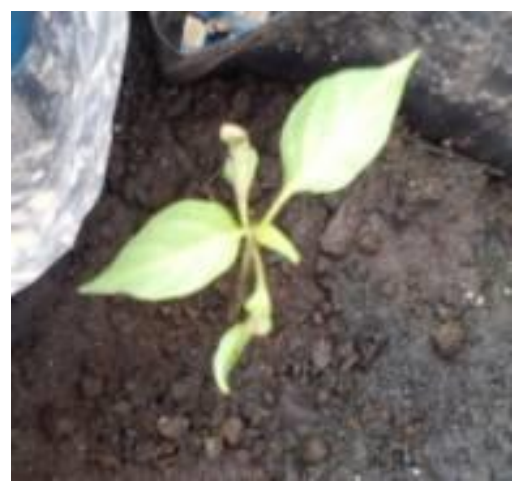

mengalami kelayuan mulai dari bagian bawah, menguning dan menjalar ke atas. Bila infeksi berkembang tanaman menjadi layu secara keseluruhan. Warna jaringan akar dan batang menjadi coklat.

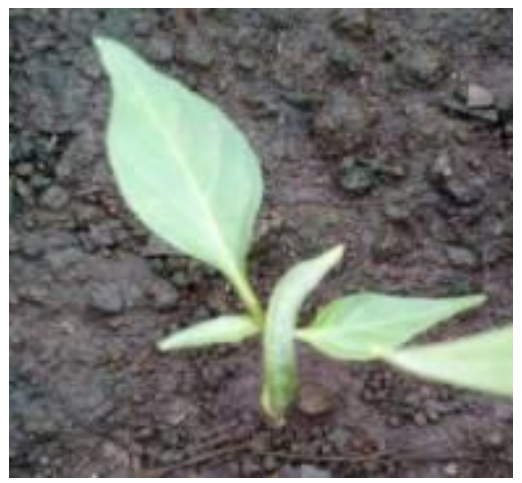

Gambar 8. Bentuk daun abnormal akibat serangan jamur patogen (a) S. rolfsii dan (b) F. oxysporum

Jamur Fusarium oxysporum masuk kedalam tanaman cabai dan menyerang pada bagian akar menuju pembuluh xilem dan mengganggu transport air sehingga stomata daun menutup dan menyebabkan tanaman layu. Dalam pembuluh xilem Fusarium oxysporum membebaskan polyfenol yang diubah menjadi quinon dan mengalami polimerasi menjadi melamin sehingga batang tanaman menjadi berwarna sawo matang (coklat). Racun yang dikeluarkan oleh cendawan tersebut menyebabkan tanaman cepat kehilangan air dan akhirnya terjadi kelayuan (Faizah dkk.,2012). Hal yang sama terjadi selama pengamatan yang menunjukkan jumlah laun yang terbentuk menurun dibandingkan dengan kontrol. Batang yang terganggu 
fungsinya akan menyebabkan transportasi nutrisi terhambat sehingga mengakibatkan pertumbuhan daun terhalang bahkan tidak terjadi.

Namun dengan pemberian bakteri kitinolitik NR09 dalam media pembawa mampu menghambat infeksi tanaman yang lebih parah dengan cara melisis dinding sel jamur patogen dengan menggunakan enzim kitinase yang dihasilkannya sehingga jumlah daun yang hasilkan tidak berbeda jauh dengan control namun tetap mengalami penurunan jumlah dan berpengaruh pada morfologi daun cabai (Gambar 8). Hal ini juga didukung melalui penelitian yang telah dilakukan Rukmana (2003) yaitu menjelaskan gejala visual yang disebabkan infeksi $F$. oxysporum seperti warna daun tanaman memucat, pembuluh batang berwarna coklat kemudian tanaman akan layu dan mati.

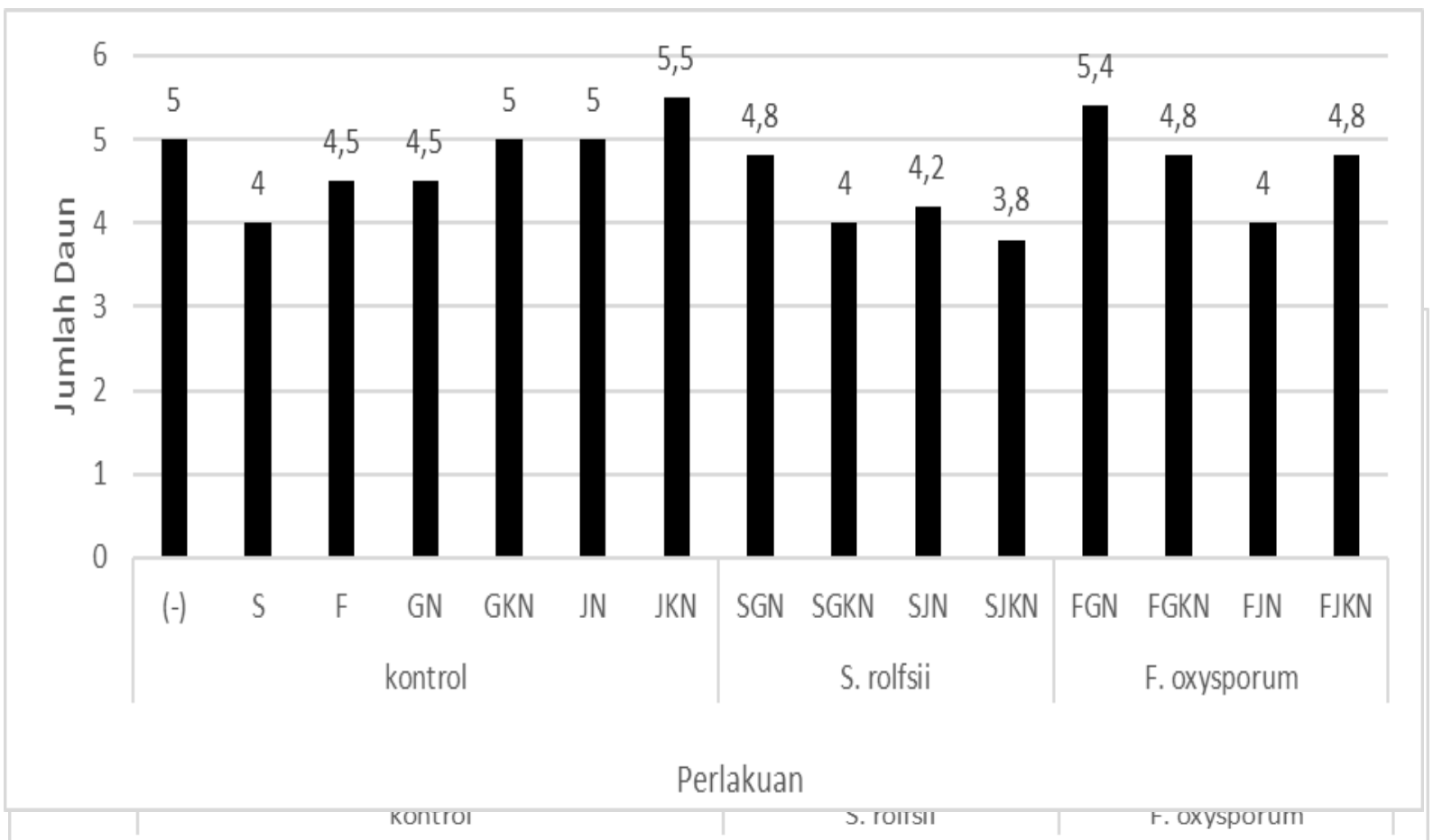

Gambar 9. Jumlah daun kecambah cabai setelah perlakuan isolat bakteri NR09 dalam media pembawa yang berbeda

\section{Reisolasi Jamur Patogen dan Bakteri kitinolitik NR09}

Reisolasi dilakukan untuk membuktikan bahwa jamur adalah satusatunya penyebab layu fusarium pada bibit cabai. Semua sampel bibit dengan gejala layu fusarium menunjukkan bahwa jamur tersebut patogen pada bibit. Reisolasi jamur patogen dilakukan pada tanaman yang terserang penyakit rebah kecambah (Gambar 8), bagian pangkal akar rusak dengan gejala pangkal batang mengering yang kemudian akan diikuti kekeringan pada seluruh tubuh tanaman. Hal ini yang menyebabkan kecambah layu dan mati. Hasil reisolasi dari kecambah cabai sama dengan isolat awal. Dengan demikian $F$. oxysporum dan $S$. rolfsii merupakan jamur patogen penyebab rebah kecambah pada cabai. 
Hutauruk, D.S.,. Potensi Bakteri Kitinolitik NR09 pada Beberapa Media Pembawa dalam Menghambat
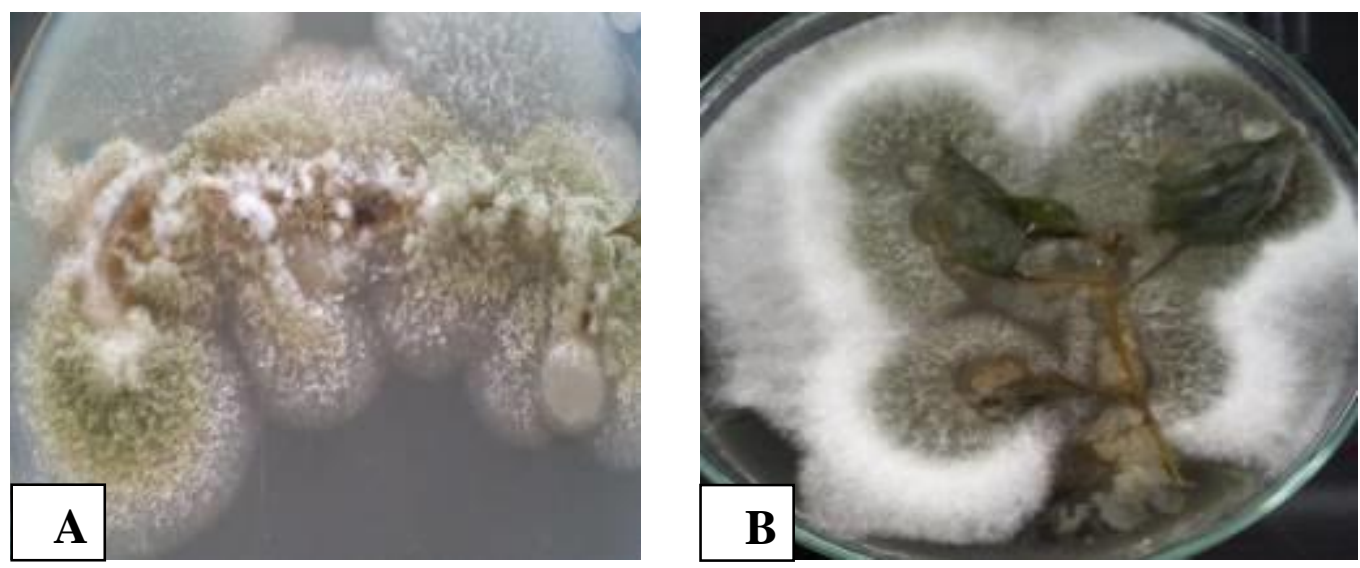

Gambar 10. Reisolasi jamur patogen dari tanaman cabai pada media PDA (A) reisolasi jamur patogen $F$. oxysporum dan (B) reisolasi jamur patogen $S$. rolfsii Jamur $F$. oxysporum memiliki Miselium bersekat dan membentuk miselium yang bersekat terutama terdapat di dalam sel, khususnya pembuluh kayu. Pada media PDA mulamula miselium berwarna putih, semakin tua warna menjadi krem atau kuning pucat. Dalam keadaaan tertentu berwarna merah muda agak ungu. percabangan.

Jamur kitinolitik NR09 yang digunakan ternyata mampu menjadi bakteri endofit dalam pangkal batang tanaman cabai merah. Hal ini dapat dilihat dari reisolasi bakteri yang dilakukan pada media MGMK (Gambar 11).

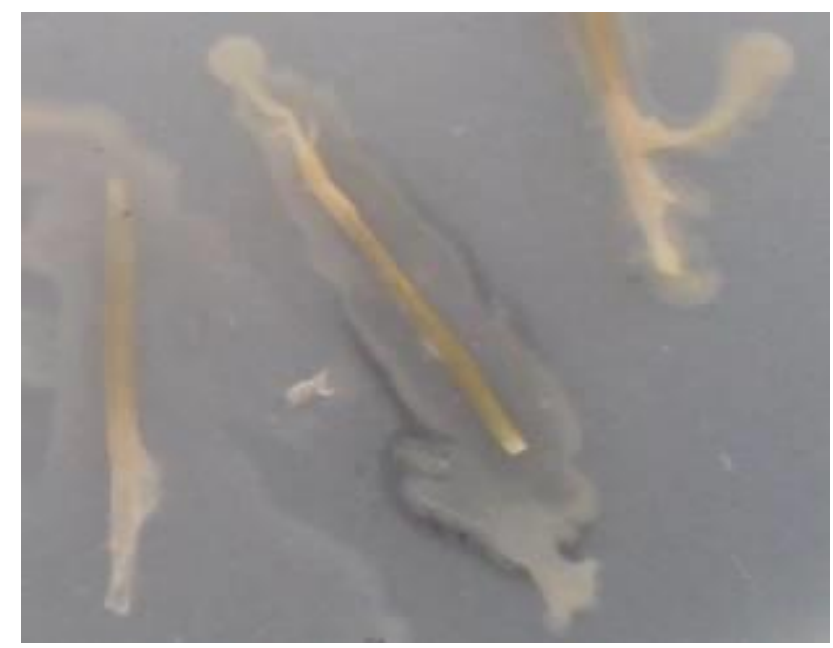

Gambar 11. Reisolasi Bakteri kitinolitik NR09 dalam pangkal batang tanaman cabai pada media MGMK 


\section{SIMPULAN}

Bakteri kitinolitik NR09 memiliki potensi menekan pertumbua jamur patogen F.oxysporum dan S. rolfsii yang menginfeksi kecambah cabai merah yang dapat dilihat dari pertumbuhan tanaman cabai. Hal ini didukung dengan viabilitas bakteri kitinolitik NR09 yang tetap tinggi baik dalam berbagai media pembawa maupun media pertumbuhan.

\section{DAFTAR PUSTAKA}

Alcivar, A., J. Jacobson, J. Rainho. 2007. Genetic Analysis of Soybean Plant Height, Hypocotyl and Internode Lengths. J AgriFoodEnviron Scie 1(1): 1-20.

Anggraeni, D.N., Usman, M., (2015), Uji Aktivitas dan Identifikasi Jamur Rhizosfer pada Tanah Perakaran Tanaman Pisang (Musa paradisiaca) Terhadap Jamur Fusarium, BioLink, Vol. 1 (2): 89-98.

Chamzurni, T., Ulim, M., A., Dianur, E. 2010. Uji ketahanan beberapa varietas tomat terhadap penyakit layu Fusarium (Fusarium oxysporum f. sp. Lycopesici). Agrista Vol 14 (2): $62-67$

Jasinski, S.M. 200o. Peat. US Geologycal Survey: US Departement of the interior.

Justice, O.L. and L.N. B ass. 2002. Prinsip dan Praktek Penyimpanan Benih. Rennie Roesli. Raja Grafindo Persada. Jakarta.

Pulungan, A.S S., (2017), Aktivitas Antijamur Ekstrak Etanol Daun Kunyit (Curcuma longa
LINN.) Terhadap Jamur Candida albicans, BioLink, Vol. 3 (2), Hal: 124-128

Putri, S.M. 2011. Efektivitas Sterilisasi Iradiasi Sinar Gamma Co-6o Dan Mesin Berkas Elektron Terhadap Berbagai Bahan Pembawa Serta Viabilitas Inokulan Dalam Bahan Pembawa Arang Batok Dan Zeolit. FP IPB. Bogor.

Permadi, M.A., Anwar, R., Santoso, T, 2017, Pemanfaatan Cendawan Beauveria bassiana (Bals.) Vuill. Sebagai Mikro-insektisida terhadap Kutu Loncat Jeruk Diaphoria citri Kuw. (Hamiptera:Liviidae), BioLink, Vol. 4 (1): Hal. 82-89.

Ratnawati, Kardhinata, E.H., Sartini, (2016), Identifikasi dan Penentuan Jenis Cendawan yang Menginfeksi Kulit Pasien Balita di Rumah Sakit Umum Pusat Haji Adam Malik Medan, BioLink, Vol. 2 (2), Hal :90-99.

Suryanto, D., S. Patonah \& E. Munir. 2010. Control of Fusarium Wilt of Chili With Chitinolytic Bacteria. Hayati J. Bio sci 17 (1) :5-8.

Sutarini, N. W., Sumiartha, I., Suniti, N., Sudiarta, I., Wirya, G., Utama, M., 2015. Pengendalian Penyakit Layu Fusarium pada Tanaman Cabai Besar (Capsicum annuum L.) dengan Kompos dan Pupuk Kandang yang dikombinasikan dengan Trichoderma sp. di Rumah Kaca. Agroekotekonologi Tropika Vol 4 (2) : 135 144

Wadani, S., A.,T., Yuliani, Rahayu, Y. S., 2015. Uji Ketahanan Lima Varietas Tanaman Cabai Merah (Capsicum annuum) terhadap Penyakit Tular Tanah (Fusarium oxysporum f.sp capsici). LenteraBio Vol.4 No.3 : 155-16o. 